\title{
Usaha Peningkatan Kualitas pH Air dan Monitoring Berbasis Mikrokontroller pada Budidaya Ikan Mujaer di Desa Brumbun Kecamatan Maduran Kabupaten Lamongan
}

\author{
Mukti Ali ${ }^{1}$, Zainal Abidin ${ }^{2 *}$ \\ ${ }^{1}$ Program Studi Budidaya Perikanan, Fakultas Perikanan, Universitas Islam Lamongan \\ ${ }^{2}$ Program Studi Teknik Elektro, Fakultas Teknik, Universitas Islam Lamongan \\ * Correspondence author: zainalabidin@ unisla.ac.id ; Tel.: 081233532045
}

Received: 29 Agustus 2019; Accepted: 26 September 2019; Published: 28 September 2019

\begin{abstract}
The aquaculture business is one of the businesses in the fishery sector that is very important in exploiting natural resources and improving the welfare of the community. The detailed studies are needed from the initial selection of fish seedlings, cultivation management and post-harvest management. Brumbun Village is one of the villages that have potential for aquaculture businesses, especially freshwater fish cultivation, especially tilapia. The village government is planning to develop the cultivation of tilapia fish as one of the leading village communities. However, there are several problems, especially in the quality of water used for cultivation purposes, the $\mathrm{pH}$ value of water is still around 4-5 so it must be increased to 7-8. Supporting this effort requires efforts to intensify fisheries cultivation, water management and efforts to maintain water quality. 328 microcontroller is used as a tool to monitor the process of improving water quality $(\mathrm{pH})$ and also scheduling feeding on tilapia fish farming.
\end{abstract}

Keywords: aquaculture, tilapia fish, monitoring, microcontroller

\section{Pendahuluan}

Desa Brumbun adalah salah satu desa di wilayah Kecamatan Maduran yang memiliki luas $3,92 \mathrm{~km}^{2}$ adalah wilayah yang hampir memiliki kesamaan potensi dengan beberapa wilayah desa di sekitarnya. Sebagian besar wilayah desa dimanfaatkan sebagai lahan pertanian, yakni 2/3 bagian dari luas desa (1). 
Masyarakat dalam hal ini pemerintahan desa Brumbun dalam rencana pengembangan potensi pengelolaan sumber daya desa merencanakan pengelolaan sebagian lahan untuk sektor perikanan. Sektor ini sudah dimulai oleh sebagian masyarakat secara individual untuk budi daya ikan air tawar, seperti bandeng, ikan lele dan nila. Namun pengelolaan belum maksimal dikarenakan belum banyak pengetahuan tentang budidaya perikanan dan juga kualitas air untuk budi daya (2).

Permasalahan dalam program ini adalah : (a) Bagaimana model usaha peningkatan kualitas air $(\mathrm{pH})$ pada budi daya ikan mujair di desa Brumbun Maduran Kabupaten Lamongan? dan (b) Bagaimana sistem monitoring pelaksanaan peningkatan kualitas air $(\mathrm{pH})$ dan penjadwalan pemberian pakan?

\section{Metode}

Ada dua metode yang digunakan dalam pelaksanaan program pengabdian masyarakat ini yakni, metode penyuluhan dan praktek lapangan tentang pengolahan kualitas air $(\mathrm{pH})$ tambak dalam budidaya ikan mujair dan metode perencanaan sistem kontrol mikrokontroller untuk penjadwalan pemberian pakan dan monitoring $\mathrm{pH}$ air.

\section{Langkah-langkah dalam Metode Penyuluhan}

Untuk memulai budidaya ikan nila di kolam tanah, perlu langkah-langkah persiapan pengolahan tanah.Mulai dari penjemuran, pembajakan tanah, pengapuran, pemupukan hingga pengairan. Berikut langkah-langkahnya:

- Langkah pertama adalah pengeringan dasar kolam. Kolam dikeringkan dengan cara dijemur. Penjemuran biasanya berlangsung selama 3-7 hari, tergantung kondisi cuaca. Sebagai patokan, penjemuran sudah cukup bila permukaan tanah terlihat retak-retak, namun tidak sampai membatu. Bila diinjak masih meninggalkan jejak kaki sedalam 1$2 \mathrm{~cm}$.

- Kolam yang telah dipakai biasanya memiliki tingkat keasaman tinggi ( $\mathrm{pH}$ rendah), kurang dari 6. Padahal kondisi pH optimal untuk budidaya ikan nila ada pada kisaran 7-8. Untuk menetralkannya lakukan pengapuran dengan dolomit atau kapur pertanian. Dosis pengapuran disesuaikan dengan keasaman tanah. Untuk $\mathrm{pH}$ tanah 6 sebanyak 500 $\mathrm{kg} / \mathrm{ha}$, untuk pH tanah 5-6 sebanyak 500-1500 kg/ha, untuk pH tanah 4-5 sebanyak 13 ton/ha. Kapur diaduk secara merata. Usahakan agar kapur bisa masuk ke dalam permukaan tanah sedalam $10 \mathrm{~cm}$. Kemudian diamkan selama 2-3 hari. 
- Setelah itu lakukan pemupukan. Gunakan pupuk organik sebagai pupuk dasar. Jenisnya bisa pupuk kompos atau pupuk kandang. Pemberian pupuk organik berguna untuk mengembalikan kesuburan tanah. Dosisnya sebanyak 1-2 ton per hektar. Pupuk ditebar merata di dasar kolam. Biarkan selama 1-2 minggu. Setelah itu, bila dipandang perlu bisa ditambahkan pupuk kimia berupa urea 50-70 kg/ha dan TSP $25-30 \mathrm{~kg} / \mathrm{ha}$, diamkan 1-2 hari. Tujuan pemupukan untuk memberikan nutrisi bagi hewan dan tumbuhan renik yang ada di lingkungan kolam. Sehingga hewan atau tumbuhan tersebut bisa dimanfaatkan sebagai pakan alami ikan.

- Langkah selanjutnya, kolam digenangi dengan air. Pengairan dilakukan secara bertahap. Pertama, alirkan air ke dalam kolam sedalam 10-20 cm. Diamkan selama 35 hari. Biarkan sinar matahari menembus dasar kolam dengan sempurna, untuk memberikan kesempatan pada ganggag atau organisme air lainnya tumbuh. Setelah itu isi kolam hingga ketinggian air mencapai $60-75 \mathrm{~cm}$.

\section{Langkah-langkah Metode Perencanaan Sistem}

1. Mengumpulkan data-data, referensi penunjang tentang mikrokontroler, Minimum system mikrokontroler, sensor $\mathrm{pH}$, sensor ultrasonik, software pemograman.

2. Perancangan alat-alat hardwere dan software

Diagram alir sistem sebagai berikut :

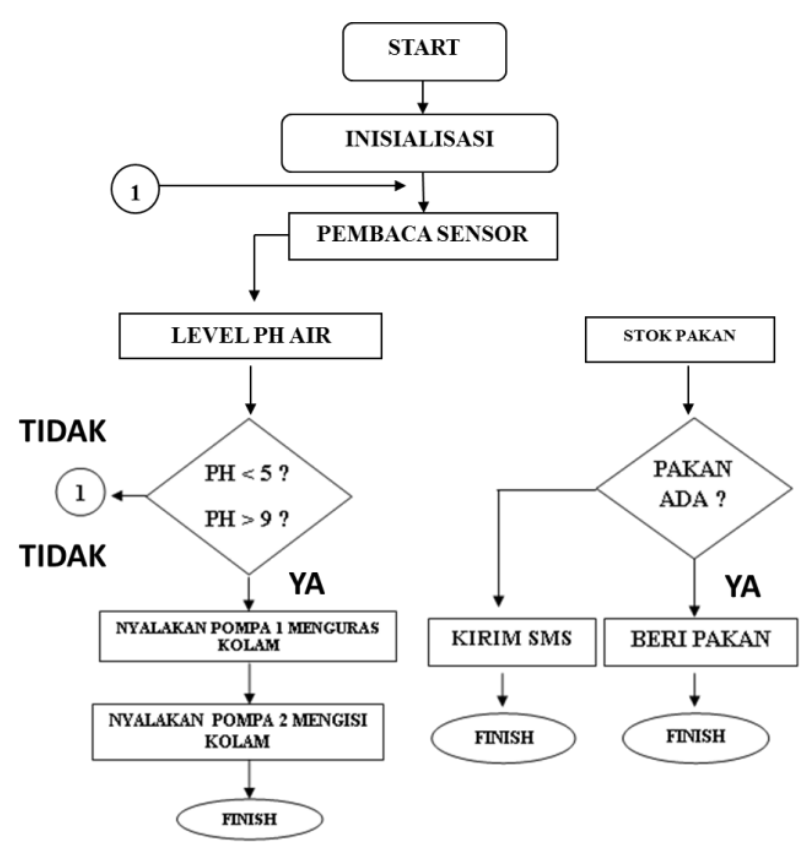

Gambar 1. Diagram Alur Sistem 
Sesuai dengan gambar di atas system kontrol $\mathrm{pH}$ air akan bekerja berdasarkan input dari sensor $\mathrm{pH} 4502 \mathrm{C}$ yang diletakan di dalam air kolam tempat budidaya ikan lele. Sensor $\mathrm{pH}$ 4502C ini akan akan memberikan perintah pada ATMega328 kemudian akan diteruskan ke relay, yaitu saat terdeteksi pH di bawah 5 atau di atas 9 maka ATMega328 secara otomatis akan menyalakan relay 1 yang terhubung ke water pump 1 yang bertindak sebagai penguras air kolam dan debit air pada kolam pun berkurang secara berkelanjutan maka relay 2 menyalakan water pump 2 untuk mengisi kembali air kolam dengan air yang baru, setelah terdeteksi oleh $\mathrm{pH}$ meter kondisi $\mathrm{pH}$ air sudah kembali normal antara 6-8, maka informasi tersebut akan di terima oleh sensor $\mathrm{pH}$ air dan meneruskannya ke ATMega328 untuk secara otomatis mematikan water pump 1 dan water pump 2.

Prinsip sistem kerja alat ini di awali dari yang pertama: mulai Start kemudian inisialisasi pin ATMega 328 selanjutnya membaca data yang sudah di atur di dalam RTC (real time clock), Jika stok pakan masih tersedia pada tabung maka akan menjadi acuan mikrokontroller menjalankan sistem yang telah ditentukan secara sistematis. (YA), jika kondisi pakan dalam tabung habis (TIDAK) maka mikrokontroller akan mengirimkan tanda atau indikator pada modul GSM dan di teruskan ke smartphone pembudidaya, Jika pH air turun sampai diangka 5 atau sebaliknya naik sampai angka 9 maka akan menjadi acuan mikrokontroller menjalankan sistem yang telah ditentukan secara sistematis (YA), jika kondisi pH air masih dalam keadaan normal (TIDAK) maka system akan kembali ke pembacaan sensor, jika YA oleh mikrokontroller menampilkan sebuah indikator pada LCD selanjutnya mikrokontroller akan menyalakan pompa air 1 untuk menguras air dalam kolam sesuai waktu yang telah ditentukan, secara berkelanjutan jika level air pada kolam berkurang maka secara otomatis akan menyalakan pompa air 2 untuk mengisi air dalam kolam dengan waktu yang telah ditentukan.

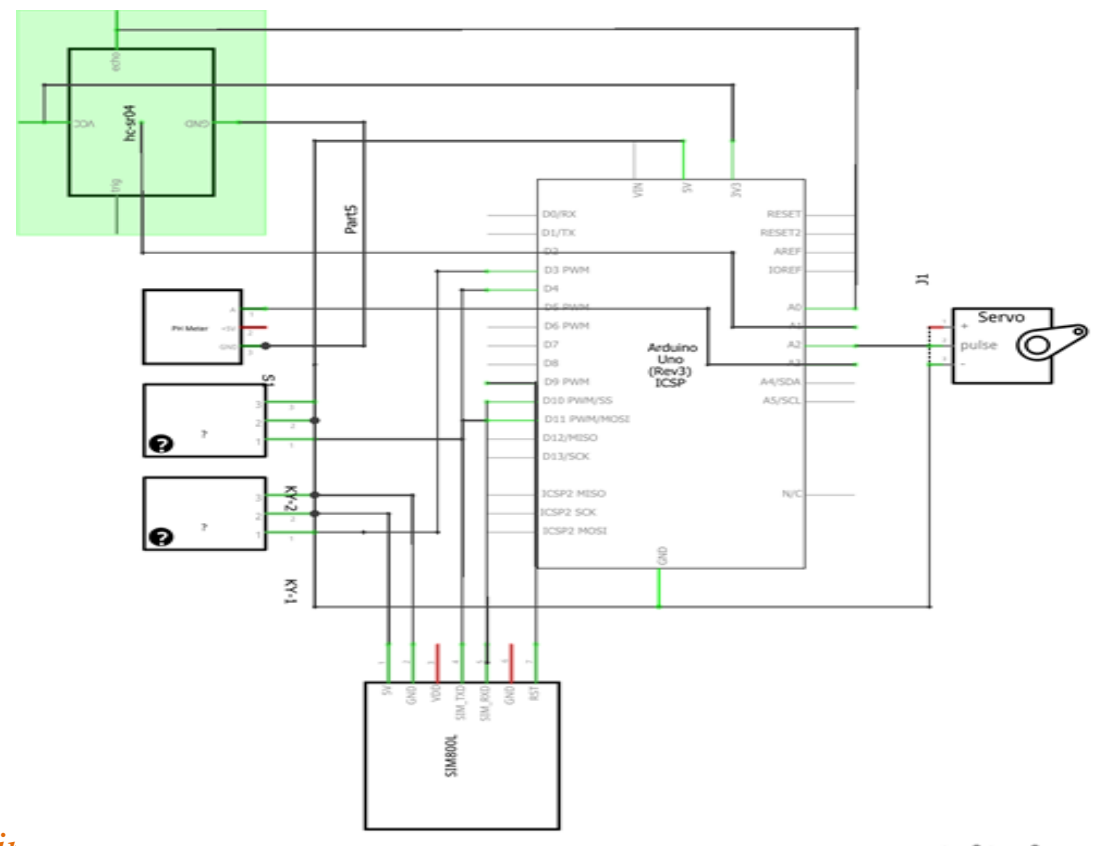


Gambar 2. Diagram Blok sistem Mikrokontroler

\section{Hasil penelitian}

Dalam hal ini model sistem masih dalam bentuk simulasi yang dapat disampaikan sebagai berikut :

\section{- Pengujian Sensor pH}

Pengujian sensor $\mathrm{pH}$ dilakukan untuk mendeteksi tingkat keasaman yang ada di dalam air untuk perkembangbiakan ikan lele. Pengujian terhadap sensor $\mathrm{pH}$ dilakukan dengan cara menghubungkan kabel dari sensor $\mathrm{pH}$ ke arduino dan hasilnya akan ditampilkan pada LCD

Tabel 1. Hasil Sensor $\mathrm{pH}$

\begin{tabular}{cccc}
\hline $\begin{array}{c}\text { Percobaan } \\
\text { Ke }\end{array}$ & $\begin{array}{c}\text { Sensor Ph } \\
\text { Digital Terkalibrasi }\end{array}$ & $\begin{array}{c}\text { Sensor } \mathbf{~ H H} \\
4502 C\end{array}$ & Selisih \\
\hline 1 & $\mathbf{8 , 1}$ & $\mathbf{7 , 9}$ & $\mathbf{0 , 2}$ \\
\hline 2 & 7,7 & 7,3 & 0,3 \\
\hline 3 & 7,8 & $\mathbf{8 , 1}$ & 0,3 \\
\hline 4 & 4,0 & 4,5 & 0,5 \\
\hline 5 & 6,0 & 6,0 & 0 \\
\hline 6 & 9,0 & 9,0 & 0,1 \\
\hline Rata-rata & 7,0 & 7,0 & 0 \\
\hline
\end{tabular}

Dari hasil tabel diatas, dilakukan pengujian menggunakan beberapa nilai kadar $\mathrm{pH}$ yang diukur mulai pH 4 - 9 didapatkan hasil pengujian dan perbandingan deng $\mathrm{pH}$ meter digital yang telah terkalibrasi hasilnya sama itu menandakan bahwa sensor $\mathrm{pH}$ yang digunakan bekerja dengan baik dan normal.

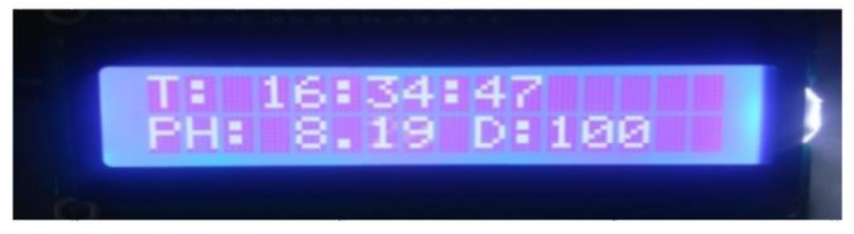

Gambar 3. Pengujian Sensor pH 


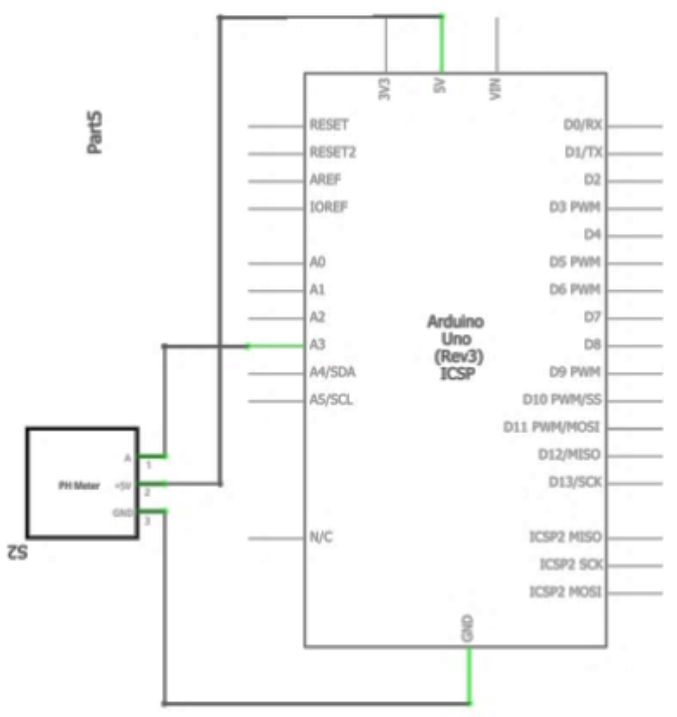

\section{fritzing}

Gambar 4. Skematik Pengujian Sensor pH

\section{Pengujian Sensor Ultrasonik}

Pengujian Sensor Ultrasonik menggunakan board Arduino Uno sebagai alat untuk memerintakan sensor akan medeteksi obyek dan setelah terdeteksi alat akan berjalan sebagaimana sistem yang telah ditentukan sesuai keinginan, dengan cara memasukan program kedalam IC Mikrokontroler ATMega328 dapat juga di pantau melalui serial monitor arduino.

Pengujian Sensor Ultrasonik dilakukan untuk memantau kondisi pakan yang tersedia masih cukup atau harus di isi kembali, jika kondisi pakan habis dan terdeteksi oleh sensor ultrasonik maka sensor ultrasonik akan menampilkannya di LCD setelah itu meneruskannya ke sistem yang telah ditentukan.

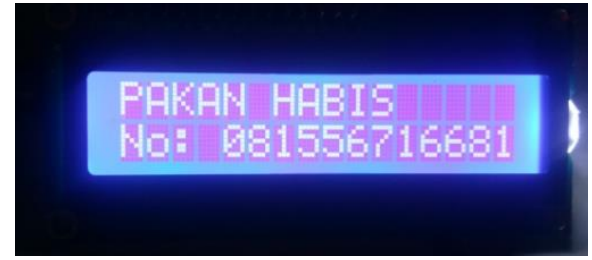

Gambar 5. Pengujian Sensor Ultrasonik

Sensor ultrasonik membaca keaadaan pakan dan meneruskan ke modul GSM ditampilkan pada Gambar 5. 


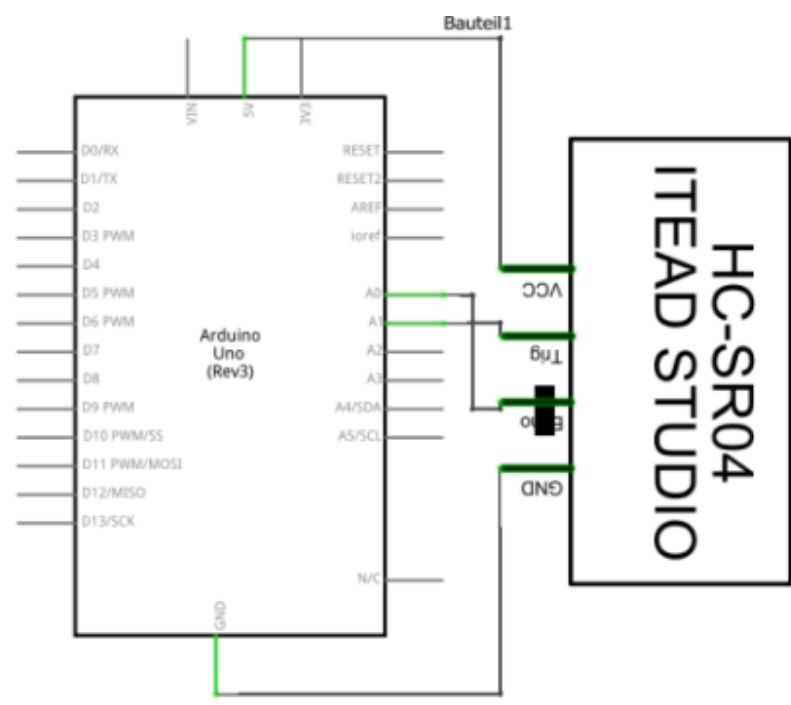

U2

\section{fritzing}

Gambar 6 Skematik Pengujian Sensor Ultrasonik

\section{Pengujian Modul GSM}

Pengujian modul GSM membutuhkan perangkat tambahan seperti board arduino uno sebagai alat untuk memerintah atau sebagai otak dari modul GSM, modul GSM akan mengirim sms kepada nomor smartphone yang sudah terdaftar pada program yang telah di masukan ke dalam IC Mikrokontroler ATMega328.

Pengujian modul GSM dilakukan untuk memastikan bahwa alat dapat mengirimkan sms ke smartphone yang telah terdaftar pada program untuk memastikan ketersediaan pakan ikan bila pakan habis maka secara otomatis akan mengirim sms ke nomor yang telah terdaftar.

\section{PHKAM HABIS \\ Hö 681556716681}

Gambar 7. Pengujian Modul GSM 


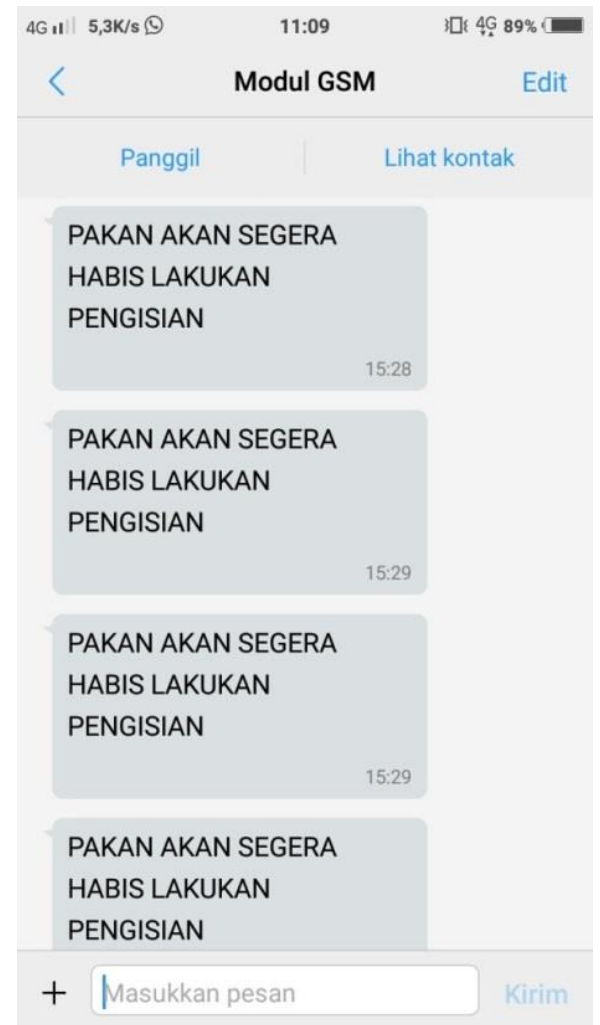


Gambar 8. Pengujian modul GSM

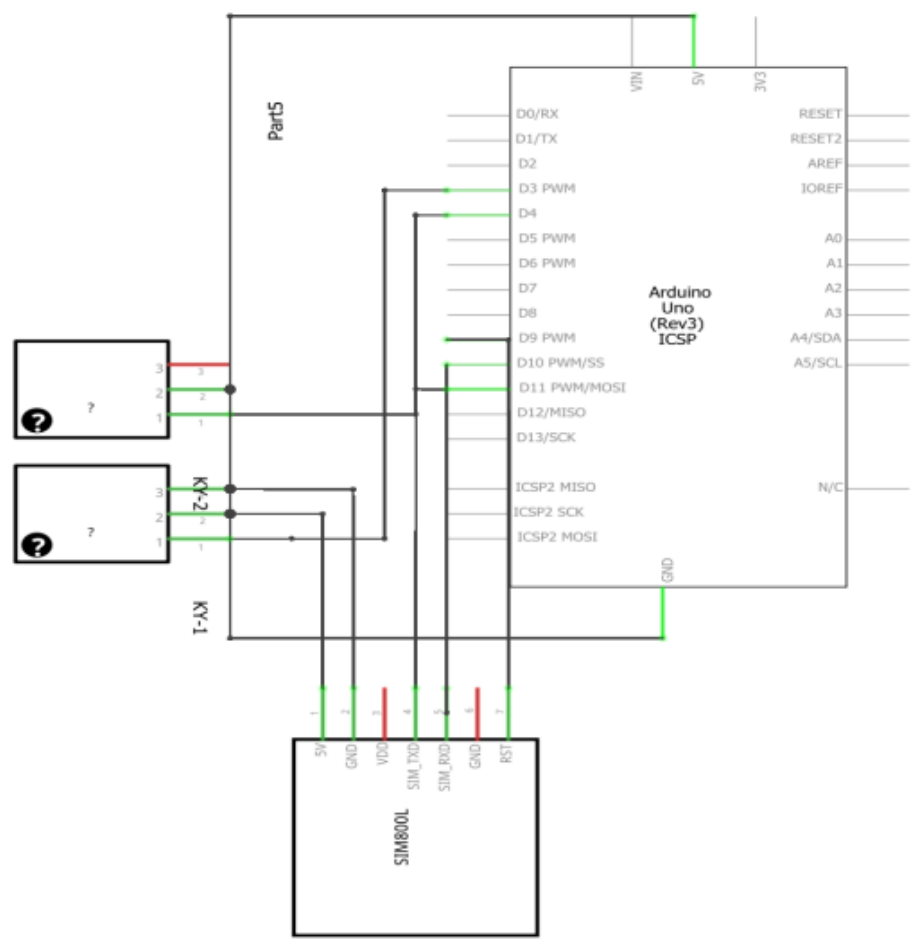

fritzing

Gambar 9. Skematik pengujian modul GSM

\section{Pengujian Motor Servo}

Pengujian motor servo membutuhkan perangkat tambahan seperti board arduino uno yang di pakai untuk memasukan program software dan menjadi penggerak dari motor servo yang bisa kita atur berputar sekian derajat.

Pengujian motor servo dilakukan untuk memastikan bahwa motor servo dapat bekerja dengan baik atau tidak karena pada saat pemberian pakan pada jam yang telah di jadwalkan di dalam program, servo akan membuka atau menutup.

\section{Pengujian Water Pump}

Pengujian water pump membutuhkan board arduino uno, sensor $\mathrm{pH}$ dan juga relay, untuk mengujinya pertama masukan program ke IC mikrokontroler ATMega328 kemudian sensor $\mathrm{pH}$ akan membaca kondisi air dalam kolam jika $\mathrm{pH}$ air di bawah 6 atau di atas 8 maka akan meneruskan ke arduino, arduino membuat perintah menyalakan water pump 1 untuk menguras 
dan berkelanjutan setelah selesai menguras maka water pump 2 akan menyala mengisi air dalam kolam dengan relay yang menjadi saklar penghubung dan pemutus arus listrik water pump.

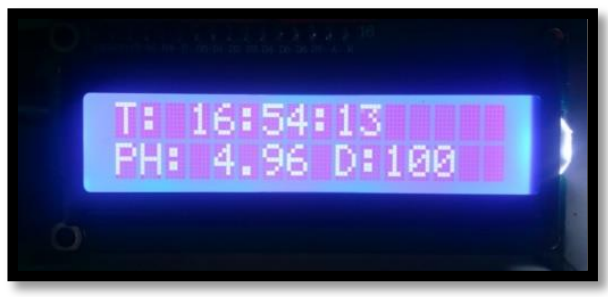

Gambar 10. Pengujian Water Pump

(Menguras sekaligus mengisi kolam jika keadaan $\mathrm{pH}$ air kolam di bawah 6 atau di atas 8)

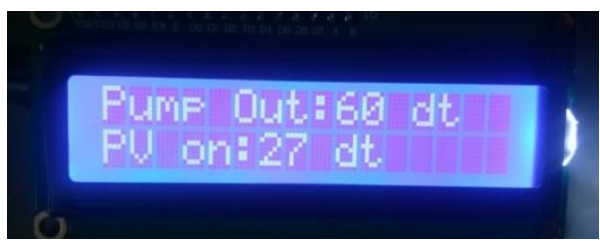

Gambar 11. Pengujian Water Pump

(menunjukan pump 1 sedang menguras kolam)

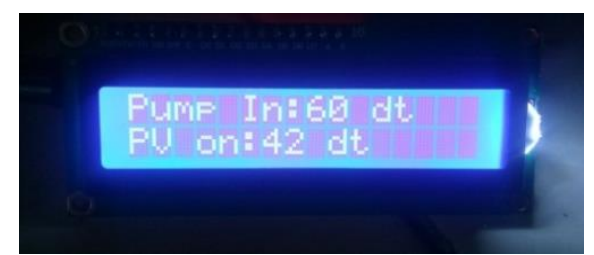

Gambar 12. Pengujian Water Pump

(menunjukan pump 2 sedang mengisi kolam)

\section{Tabel 2. Pengujian keseluruhan alat}

Setelah dilakukan pengujian selama satu minggu, system budidaya ikan mujair di peroleh hasil bahwa system kontrol otomatis ini bisa bekerja dengan baik.

\section{Pembahasan}


Dalam hal ini, akan akan dibahas hasil dari pengujian rangkaian alat yang meliputi pengujian sensor $\mathrm{pH}$, sensor ultrasonik, modul GSM, RTC, motor servo, pengujian LCD, water pump dan pengujian rangkaian secara kseluruhan yang telah terintegrasi.

Sensor $\mathrm{pH}$ dipasang digunakan untuk mendeteksi besar nilai zat asam yang ada di dalam kolam untuk kelangsungan perkembangbiakan ikan lele. Dari pengujian yang dilakukan di dapatkan besar nilai zat asam yang berada di dalam kolamakan tampil pada LCD. Melihat hasil di dapat dari uji coba tabel 4.2 diatas menunjukan hasil deteksi sensor $\mathrm{pH}$ bekerja secara normal dan berfungsi dengan baik (3).

\begin{tabular}{ccccccc}
\hline $\begin{array}{c}\text { Hari } \\
\text { Ke }\end{array}$ & $\begin{array}{c}\text { pH } \\
\text { air }\end{array}$ & $\begin{array}{c}\text { Water } \\
\text { Pump 1 } \\
\text { (Menguras) }\end{array}$ & $\begin{array}{c}\text { Water } \\
\text { Pump 2 } \\
\text { (Mengisi) }\end{array}$ & Servo & LCD & GSM \\
\hline 1 & 9 & ON & ON & Beri Pakan & Pakan Ada & OFF \\
\hline 2 & 8 & OFF & OFF & Beri Pakan & Pakan Ada & OFF \\
\hline 3 & 5 & ON & ON & Beri Pakan & Pakan & Kirim Sms \\
& & & & & Habis & \\
\hline 4 & 7 & OFF & OFF & Beri Pakan & Pakan Ada & OFF \\
\hline 5 & 6 & OFF & OFF & Beri Pakan & Pakan & Kirim Sms \\
& & & & & Habis & \\
\hline 6 & 7 & OFF & OFF & Beri Pakan & Pakan Ada & OFF \\
\hline 7 & 7 & OFF & OFF & Beri Pakan & Pakan Ada & OFF \\
\hline
\end{tabular}

Kaki - kaki LCD disambungkan ke modul I2C kemudian dihubungkan pada pin mikrokontroler dan diberi input tegangan yang berguna untuk mengatur keluaran nilai analog dari masing - masing button yang tersedia pada LCD. Dilakukan upload program program sederhana yang tersedia pada program example arduino, seperti helloword untuk menguji rangkaian LCD. Pengujian LCD dilakuan untuk memastikan semua data yang di hasilkan ileh sensor bisa tampil dan dapat di pantau dengan mudah lewat LCD.

Motor servo dan RTC keduanya saling terhubung ke pin arduino dengan memasukan program yang mengatur motor servo akan berputar berapa derajat dan RTC mengatur sebagai penjadwal pemberian pakan secara otomatis yang akan di gerakan oleh motor servo jadi kedua komponen ini harus sama - sama dalam kondisi normal agar di dapatkan hasil yang maksimal. Berdasarkan uji coba selama satu minggu kedua komponen ini berjalan seperti yang telah di rencanakan dan tidak ada masalah atau eror pada kinerja kedua komponen ini. 
Water pump alat yang ini di letakan dalam air kolam berguna umtuk menjaga kondisi $\mathrm{pH}$ air yang di pantau oleh sensor $\mathrm{pH}$, jika kondisi $\mathrm{pH}$ air dalam kolam menurun drastis sampai di angka 5 atau naik sampai angka 9 maka secara system yang telah di rancang $\mathrm{pH}$ sensor akan memberikan isyarat di tampilkan melalui LCD yang akan di teruskan ke arduino dan arduino akan menyalahkan relay sebagai saklar otomatis untuk menyalakan atau mematikan water pump, water pump 1 untuk menguras kemudian di lanjutkan oleh water pump 2 akan menyala dan mengisi air kolam.

Secara keseluruhanpemberian pakan yang baik untuk ikan mujair dalam satu hari atau 24 jam adalah 4 kali .Penting bagi kita menjadwal pemberian pakan yang tepat waktu dan pada alat ini telah di jadwalkan oleh RTC dari jam 06:00, 12:00, 18:00 dan 24:00 (WIB) sedangkan untuk $\mathrm{pH}$ yang baik digunakan untuk perkembangbiakan ikan mujair antara $\mathrm{pH} 7-8$ diatas atau dibawahnya tidak baik bisa menyebabkan tidak tumbuh atau bisa mati.

\section{Kesimpulan}

Untuk mendesaian alat pemberi pakan otomatis dan kontrol $\mathrm{pH}$ air pada budidaya ikan mujair berbasis mikrokontroler, diperlukan berbagai komponen penting berikut, sensor $\mathrm{pH}$, sensor ultrasonik, modul GSM, motor servo, RTC, water pump, semua komponen tersebut dirangkai menjadi satu rangkaian yang berfungsi sebagai pengatur jadwal pemberian pakan secara otomatis dan kontrol $\mathrm{pH}$ air di dalam kolam yang akan di tampilkan oleh LCD.

Untuk mengatur penjadwalan pemberian pakan secara otomatis dengan adanya RTC pada alat ini yang akan mengatur pemberian pakan secara otomatis sesuai dengan penjadwalan yang telah direncanakan dan terprogram di dalam IC mikrokontroler ATMega328 kemudian akan di gerakan oleh servo, untuk kontrol $\mathrm{pH}$ air di dalam kolam akan sangat mudah dimonitoring dari tampilan LCD yang merespon input dari sensor $\mathrm{pH}$ yang diletakan di dalam kolam

\section{Daftar Pustaka}

1. Departemen Pendidikan dan Kebudayaan. (1995). Dampak Pembangunan Ekonomi (pasar) Terhadap Kehidupan Sosial Budaya Masyarakat Daerah Istemewa Yogyakarta. Yogyakarta: Depdikbud.

2. Modul Kuliah Empowerment yang Berjudul Panduan Umum pemberdayaan Masyarakat. Yogyakarta: Jurusan PMI UIN Sunan Kalijaga. 
3. Ambar Teguh Sulistiyani. (2004). Kemitraan dan Model-model Pemberdayaan. Gava Media: Yogyakarta. 